\title{
EFEKTIVITAS SISTEM COMPUTER ASSIST TEST TERHADAP KEMUDAHAN DAN KENYAMANAN DALAM MELAKUKAN PENILAIAN
}

\author{
Selli Mariko ${ }^{1}$, Halleyna Widyasari² ${ }^{2}$ dan Purni Munah Hartuti ${ }^{3}$ \\ Program Studi Teknik Informatika, Universitas Indraprasta PGRI \\ Email: sellimariko85@gmail.com ${ }^{1}$, halleynawidyasari0@ gmail.com ${ }^{2}$, \\ purniibunyahanum@yahoo.co.id ${ }^{3}$
}

\begin{abstract}
Abstrak
Tahap pembelajaran secara garis besar dibagi menjadi 3 kelompok, yaitu: tahap persiapan, tahap pelaksanaan dan tahap evaluasi. Pada studi ilmiah ini tahapan yang akan dikaji oleh peneliti akan dibatasi hanya pada tahap evaluasi. Adapun permasalahan yang akan dikaji adalah efektivitas sistem penilaian terhadap kemudahan dan kenyamanan pada evaluasi hasil belajar peserta didik. Hipotesa atau dugaan awal dari peneliti bahwa sistem penilaian dengan Computer Assist Test (CAT) efektif dalam memberikan kemudahan dan kenyamanan dalam melakukan evaluasi kompetensi peserta didik. Berdasarkan hasil analisis dan pembahasan yang disesuaikan dengan teori yang relevan dapat diambil beberapa kesimpulan, di antaranya: 1. Sistem penilaian dengan Computer Assist Test (CAT) memiliki korelasi yang kuat terhadap kemudahan dalam melakukan evaluasi kompetensi peserta didik; 2. Sistem penilaian yang baik maka akan meningkatkan kemudahan dalam melakukan evaluasi kompetensi peserta didik; 3. Sistem penilaian yang baik yang baik maka akan meningkatkan kenyamanan dalam melakukan evaluasi kompetensi peserta didik; 4. Terdapat hubungan positif dan signifikan antara sistem penilaian dengan CAT terhadap kemudahan dalam melakukan evaluasi kompetensi peserta didik. 5. Terdapat hubungan positif dan signifikan antara sistem penilaian dengan CAT terhadap kenyamanan dalam melakukan evaluasi kompetensi peserta didik.
\end{abstract}

Kata Kunci: Sistem Penilaian, Computer Assist Test dan Kompetensi Peserta Didik

\section{Pendahuluan}

Secara garis besar kegiatan pembelajaran terbagi atas tiga tahap, yaitu: tahap persiapan, tahap pembelajaran dan tahap evaluasi. Pada tahap persiapan, seorang guru/ dosen harus mempersiapkan materi yang akan disampaikan kepada peserta didiknya. Pada tahap pelaksanaan, seorang guru/ dosen harus dapat menyampaikan materi kepada peserta didiknya. Sedangkan pada tahap evaluasi, seorang guru/ dosen harus dapat mengukur tentang kompetensi yang dicapai oleh peserta didik terhadap materi yang disampaikan. Merujuk pada kegiatan pembelajaran yang sangat komprehensif maka seorang guru/ dosen perlu mendesain sebuah kegiatan pembelajaran supaya efektif untuk diterapkan pada karakteristik peserta didiknya. Oleh karena itu, dukungan komputer sebagai salah satu sarana alternatif dalam mendukung kegiatan pembelajaran.

Desain kegiatan pembelajaran dengan bantuan komputer (Computer Assist) saat ini sudah berkembang sangat pesat. Masing-masing vendor berusaha memberikan fitur-fitur dalam software aplikasinya untuk memudahkan penggunanya. Akan tetapi belum tentu dengan fitur yang lengkap maka akan meningkatkan kompetensi peserta didik. Hal ini disebabkan oleh kondisi dari guru/ dosen dan peserta didiknya pada lingkungan satuan pendidikannya. Pada sebuah satuan pendidikan yang terbiasa dengan perangkat komputer mungkin sistem ini dapat menjadi sebuah alternatif untuk meningkatkan efektivitas kegiatan pembelajaran. Akan tetapi, pada sebuah sebuah satuan pendidikan yang asing dengan perangkat komputer, maka keadaan ini justru menjadi sebuah penghambat dalam kegiatan pembelajaran.

Di SMK Taruna Bhakti guru dan peserta didik sudah terbiasa dalam menggunakan perangkat komputer untuk mendukung aktivitas kegiatan pembelajaran. Setiap peserta didik SMK 
Taruna Bhakti sudah diwajibkan untuk memliki laptop/ notebook. SMK Taruna Bhakti merupakan satuan pendidikan dengan mengedepankan kompetensi berbasis teknologi informasi. Dari awal masuk sekolah setiap peserta didik sudah dikenalkan dengan sistem pembelajaran berbasis teknologi informasi. Oleh karena itu setiap guru dituntut untuk dapat membuat sebuah materi dalam bentuk bahan ajar digital. Beberapa guru sudah mencoba untuk membuat sistem penilaian kompetensi peserta didik dengan berbantuan komputer dengan sistem yang sederhana.

Pada bulan januari 2015 Tim Abdimas LPPM Universitas Indraprasta PGRI melakukan kegiatan pengabdian masyarakat di SMK Taruna Bhakti. Kegiatan ini berupa pelatihan untuk membantu guru-guru supaya dapat membangun dan mengembangkan sendiri sebuah instrument penilaan dengan berbantuan komputer (Computer Assist Test). Dengan kegiatan ini diharapkan semua proses tahapan kegiatan pembelajaran dapat dilakukan dengan berbantuan komputer.

Untuk mengetahui seberapa jauh tentang efektivitas penggunaan komputer dalam mendukung kegiatan pembelajaran khusunya pada proses penilaian, maka akan dilakukan studi ilmiah tetang kajian tersebut. Apakah dengan sistem pembelajaran ini menjadikan kemampuan kompetensi peserta didik menjadi lebih baik atau sebaliknya. Studi ilmiah ini sangat diperlukan untuk melihat pada aspek pembelajaran berbantuan komputer yang perlu untuk diperbaiki. Selain itu studi ilmiah ini dapat digunakan untuk mendesain sebuah kegiatan pembelajaran berbantuan komputer yang lebih baik dan sempurna. Tujuan umum dalam melakukan kajian ilmiah ini, yaitu:

1. Mengetahui tingkat efektivitas sistem penilaian dengan Computer Assist Test untuk evaluasi kompetensi peserta didik.

2. Memberikan analisis tentang aspek yang mempengaruhi efektivitas sistem penilaian pada evaluasi kompetensi peserta didik.

3. Memberikan studi lebih lanjut tentang Computer Assist Test untuk mendukung kegiatan pembelajaran khususnya pada tahap penilaian peserta didik.

Dugaan awal atau hipotesis kajian ilmiah ini bahwa sistem penilaian dengan Computer Assist Test efektif dalam memberikan kemudahan dan kenyamanan dalam melakukan evaluasi kompetensi peserta didik.

\section{Tinjauan Pustaka}

Kata efektif berasal dari bahasa Inggris yaitu effective yang berarti berhasil atau sesuatu yang dilakukan berhasil dengan baik. Kamus ilmiah populer mendefinisikan efektivitas sebagai ketepatan penggunaan, hasil guna atau menunjang tujuan. Pada umumnya efektivitas sering dihubungkan dengan efisiensi dalam pencapaian tujuan organisasi. Padahal suatu tujuan atau saran yang telah tercapai sesuai dengan rencana dapat dikatakan efektif, tetapi belum tentu efisien. Walaupun terjadi suatu peningkatan efektivitas dalam suatu organisasi maka belum tentu itu efisien. Jelasnya, jika sasaran atau tujuan telah tercapai sesuai dengan yang direncanakan sebelumnya dapat dikatakan efektif. Jadi bila suatu pekerjaan itu tidak selesai sesuai waktu yang telah ditentukan, maka dapat dikatakan tidak efektif. Efektivitas merupakan gambaran tingkat keberhasilan atau keunggulan dalam mencapai sasaran yang telah ditetapkan dan adanya keterkaitan antara nilai-nilai yang bervariasi.

Menurut (Mulyasa, 2003a) mengutarakan efektivitas adalah bagaimana suatu organisasi berhasil mendapatkan dan memanfaatkan sumber daya dalam usaha mewujudkan tujuan operasional. Efektivitas sering kali berkaitan erat dengan perbandingan antara tingkat pencapain tujuan dengan rencana yang telah ditetapkan sebelumnya, atau perbandingan hasil nyata dengan hasil yang direncanakan. Sedangkan sistem penilain secara umum 
didefinisikan sebagai cara atau metode untuk mengukur kompetensi yang dikuasai oleh peserta didik.

Menurut (Muhibbin, 2008) mengartikan prestasi belajar adalah tingkat keberhasilan siswa dalam mencapai tujuan yang ditetapkan dalam sebuah program. Pendapat yang hampir sama dikemukakan oleh (Slameto, 2010), yaitu penilaian prestasi belajar merupakan sekelompok pertanyaan, tugas-tugas, penilaian dokumen hasil kerja yang harus diselesaikan oleh siswa dengan tujuan untuk mengukur kemajuan belajar siswa.

Berdasarkan uraian di atas dapat ditarik sebuah garis besar bahwa efektivitas sistem penilaian merupakan usaha untuk mewujudkan tujuan operasional melalui pertanyaan tugas dan penilaian dokumen untuk mengukur kemajuan belajar peserta didik. Sistem penilaian merupakan strategi yang dipilih oleh seorang untuk mengukur kompetensi peserta didik yang paling mudah, cepat dan akurat.

Untuk megukur kompetensi peserta didik salah satu caranya dengan menggunakan instrument test. Instrument test biasanya berisikan butir-butir pertanyaan tentang materi yang diajarkan. Seiring dengan perkembangan teknologi instrument test disajikan dalam bentuk digital untuk memudahkan seorang guru dalam melakukan penilaian. Instrument test/ penilaian dengan berbantuan komputer inilah yang saat ini lebih dikenal dengan nama Computer Assist Test (CAT). Menurut (Rusman, 2010) peningkatan mutu pembelajaran secara garis besar komputer dimanfaatkan dalam dua macam penerapan yaitu: (1) penerapan komputer dalam bentuk pembelajaran berbantuan komputer (Computer Assisted InstructionCAI), (2) penerapan komputer dalam pembelajaran berbasis komputer (Computer Based Instruction-CBI). Evaluasi merupakan suatu proses yang mencakup pengukuran dan mungkin juga testing, yang juga berisi pengambilan keputusan tentang nilai. Pendapat ini sejalan dengan pendapat (Arikunto, 1997) yang menyatakan bahwa evaluasi merupakan kegiatan mengukur dan menilai. Kedua pendapat di atas secara implisit menyatakan bahwa evaluasi memiliki cakupan yang lebih luas daripada pengukuran dan testing.

Sebagaimana yang sudah diuraikan bahwa evaluasi peserta didik dilaksanakan dengan berbagai tujuan. Menurut (Spencer, 1993) kompetensi didefinisikan sebagai an underlying characteristic's of an individual which is causally related to criterion-referenced effective and or superior performance in a job or situation. Secara singkat karakteristik mendasari seseorang dan berkaitan dengan efektivitas kinerja individu dalam pekerjaannya. Kompetensi individu yang berupa kemampuan dan pengetahuan dapat dikembangkan melalui kegiatan pendidikan dan pelatihan. Sedangkan menurut (Mulyasa, 2007b) menjelaskan bahwa kompetensi merupakan indikator yang menunjuk pada perbuatan yang bisa diamati dan sebagai konsep yang mencakup aspek-aspek pengetahuan, keterampilan, nilai dan sikap serta tahap-tahap pelaksanaannya secara utuh.

\section{Metodologi Penelitian}

Ruang lingkup kajian penelitian ini adalah jenis penelitian pengembangan. Menurut (Rusti, 2012) Penelitian pengembangan (Research and development $/ R \& D$ ) adalah metode penelitian yang digunakan untuk menghasilkan produk tertentu dan menguji keefektifan produk tersebut. Untuk dapat menghasilkan produk tertentu, digunakan penelitian yang bersifat analisis kebutuhan. Sedangkan untuk menguji keefektifan produk tersebut supaya berfungsi di masyarakat luas, maka diperlukan penelitian untuk menguji produk tersebut. Jadi penelitian pengembangan bersifat longitudinal (bertahap bisa dan multi years). Sesuai dengan namanya, Research \& Developmnet dipahami sebagai kegiatan penelitian yang dimulai dengan research dan diteruskan 
dengan development. Kegiatan research dilakukan untuk mendapatkan informasi tentang kebutuhan pengguna (needs assessment), sedangkan kegiatan development dilakukan untuk menghasilkan perangkat pembelajaran.

Penelitian ini akan mengembangkan sebuah produk baru berupa instrument penilaian dengan menggunakan sistem Computer Assist Test (CAT) yang akan diuji cobakan pada Guru Normatif dan Adaptif di SMK Taruna Bhakti. Secara sederhana tahapan dari penelitian yang akan dilakukan oleh peneliti ditampilkan dalam bagan berikut ini:

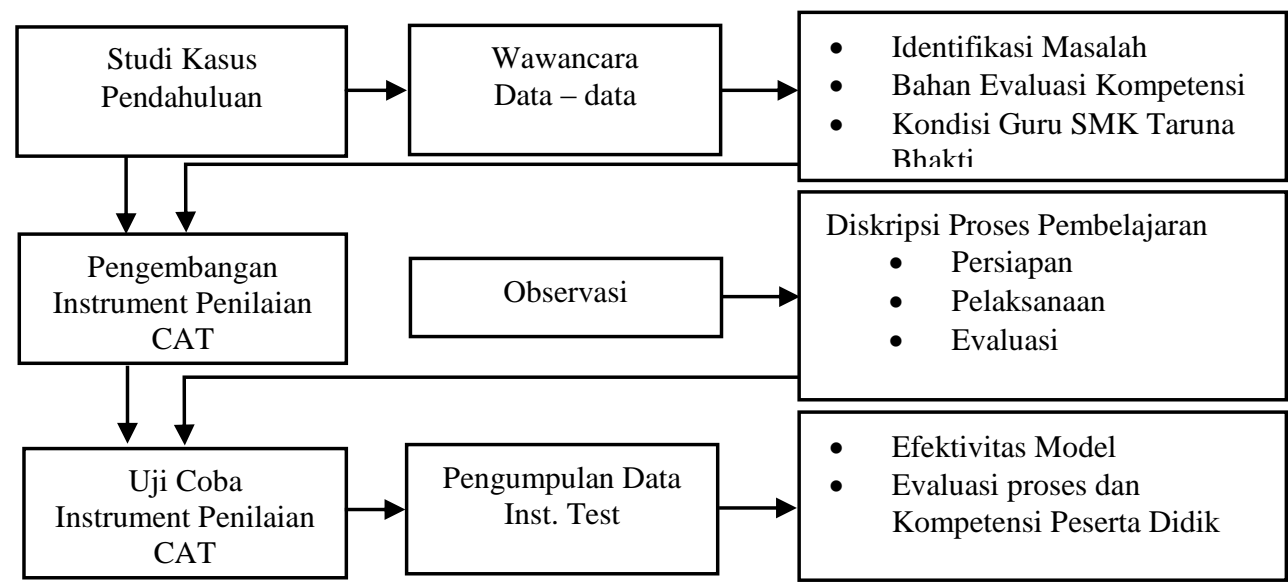

Gambar 1. Diagram Alir Tahapan Penelitian

\section{Hasil dan Pembahasan}

Berdasarkan data yang diperoleh dari skor angket yang diberikan kepada 20 orang guru bidang studi adaptif dan normativ di SMK Taruna Bhakti. Angket yang diberikan meliputi angket sistem penilaian dengan $C A T$, angket kemudahan dalam evaluasi peserta didik, dan angket kenyamanan dalam evaluasi peserta didik.

Tabel 1. Hasil Rangkuman Statistik Deskriptif

\begin{tabular}{lccccc}
\hline & N & Min & Max & Mean & Std. Deviation \\
\hline Sistem_penilaian_dengan_CAT & 20 & 4,00 & 5.00 & 4,1000 & 0,30779 \\
Kemudahan_Evaluasi & 20 & 3,00 & 5.00 & 4,1500 & 0,48936 \\
Kenyamanan_evaluasi & 20 & 4,00 & 5.00 & 4,1500 & 0,36635 \\
Valid N (listwise) & 20 & & & & \\
\hline
\end{tabular}

Untuk mengetahui efektivitas sistem penilaian dengan CAT terhadap kemudahan dan kenyamanan dalam melakukan evaluasi peneliti menggunakan analissis regresi linier dengan memanfaatkan program SPSS 17. Analisis regresi dilakukan pada: 1) Data sistem penilaian dengan $C A T$ terhadap data kemudahan evaluasi dan 2) Data sistem penilaian dengan CAT terhadap data kenyamanan evaluasi. Koefisien regresi menerangkan sejauh mana sistem penilaian dengan $C A T$ berperan sebagai prediktor terhadap kemudahan dan kenyamanan dalam melakukan evaluasi kompetensi peserta didik.

\section{Analisis Sistem Penilaian Dengan CAT Terhadap Kemudahan Dalam Melakukan Evaluasi Kompetensi Peserta Didik}


Tabel 2. Analisis Regresi Linier Sistem Penilaian dengan CAT terhadap Kemudahan dalam Melakukan Evaluasi Kompetensi Peserta Didik

\begin{tabular}{ccccc}
\hline Model & $\mathrm{R}$ & R Square & Adjusted R Square & Std. Error of the Estimate \\
\hline 1 & $0,594^{\mathrm{a}}$ & 0,353 & 0,317 & 0,4445 \\
\hline
\end{tabular}

Hasil analisis regresi linier data sistem penilaian dengan $C A T$ terhadap data kemudahan dalam melakukan evaluasi kompetensi peserta didik ditunjukkan pada tabel 4a dalam lampiran. Dari tabel 2 menunjukkan koefisien regresi $R$ sebesar 0,594 lebih besar dari $\mathrm{r}_{\text {tabel }}$ 0,444 mempunyai makna bahwa sistem penilaian dengan $C A T$ memiliki korelasi yang kuat terhadap kemudahan dalam melakukan evaluasi kompetensi peserta didik. Sementara koefisien determinasi $R^{2}$ sebesar 0,353 mempunyai makna bahwa sistem penilaian dengan $C A T$ terhadap kemudahan dalam melakukan evaluasi kompetensi peserta didik memberikan kontribusi sebesar 35,3\% sedangkan selebihnya dipengaruhi oleh faktor lain.

Tabel 3. Analisis Regresi Linier Sistem Penilaian dengan CAT terhadap Kemudahan dalam Melakukan Evaluasi Kompetensi Peserta Didik

\begin{tabular}{rlccc} 
& & Model & \multicolumn{2}{c}{ Unstandardized Coefficients } \\
& & B & Std. Error \\
\hline 1 & (Constant) & 0,278 & 1,239 \\
& SistemPenilaianDenganCAT & 0,944 & 0,301 \\
\hline
\end{tabular}

Persamaan regresi linear yang diperoleh sesuai dengan tabel 3 yaitu $Y=0,278+0,944 X$ yang berarti bahwa kenaikan satu skor sistem penilaian dengan $C A T$ memberikan kenaikan sebesar 0,944 terhadap skor kemudahan dalam melakukan evaluasi kompetensi peserta didik. Dengan sistem penilaian yang baik maka akan meningkatkan kemudahan dalam melakukan evaluasi kompetensi peserta didik.

\section{Analisis Sistem Penilaian Dengan CAT Terhadap Kenyamanan Dalam Melakukan Evaluasi Kompetensi Peserta Didik}

Tabel 4. Analisis Regresi Linier Sistem Penilaian Dengan CAT terhadap Kenyamanan dalam Melakukan Evaluasi Kompetensi Peserta Didik

\begin{tabular}{ccccc} 
Model & $\mathrm{R}$ & R Square & Adjusted R Square & Std. Error of the Estimate \\
\hline 1 & $0,793^{\mathrm{a}}$ & 0,630 & 0,609 & 0,22906 \\
\hline
\end{tabular}

Dari Tabel 4 menunjukkan koefisien regresi $R$ sebesar 0,793 lebih besar dari $\mathrm{r}_{\text {tabel }} 0,444$ mempunyai makna bahwa sistem penilaian dengan $C A T$ memiliki korelasi yang sangat kuat terhadap kenyamanan dalam melakukan evaluasi kompetensi peserta didik. Sementara koefisien determinasi $R^{2}$ sebesar 0,630 mempunyai makna bahwa sistem penilaian dengan CAT terhadap kemudahan dalam melakukan evaluasi kompetensi peserta didik memberikan kontribusi sebesar $63 \%$ sedangkan selebihnya dipengaruhi oleh faktor lain.

Tabel 5. Analisis Regresi Linier Sistem Penilaian dengan CAT terhadap Kenyamanan dalam Melakukan Evaluasi Kompetensi Peserta Didik

\begin{tabular}{lcc}
\hline & \multicolumn{2}{c}{ Unstandardized Coefficients } \\
Model & B & Std. Error \\
\hline (Constant) & 0,278 & 0,702 \\
\hline SistemPenilaianDenganCAT & 0,944 & 0,171 \\
\hline
\end{tabular}


Persamaan regresi linear yang diperoleh sesuai dengan tabel 5 yaitu $\mathrm{Y}=0278+0,944 \mathrm{X}$ berarti bahwa kenaikan satu skor sistem penilaian dengan CAT memberikan kenaikan sebesar 0,944 terhadap skor kenyamanan dalam melakukan evaluasi kompetensi peserta didik. Dengan sistem penilaian yang baik yang baik maka akan meningkatkan kenyamanan dalam melakukan evaluasi kompetensi peserta didik.

Penelitian ini bertujuan untuk mengetahui efektivitas sistem penilaian dengan menggunakan $C A T$ terhadap kemudahan dan kenyamanan dalam melakukan evaluasi kompetensi peserta didik. Sistem penilaian merupakan salah satu hal penting dalam melakukan evaluasi kompetensi, perlu dikembangkan. Sistem penilaian sangat mempengaruhi kemudahan dan kenyamanan dalam melakukan evaluasi kompetensi peserta didik. Hal ini mendorong keingintahuan efektivitas penggunaan sistem penilaian dengan menggunakan CAT terhadap kemudahan dan kenyamanan yang dirasakan oleh guru dalam melakukan evaluasi kompetensi peserta didiknya. Dalam penelitian ini tidak dilakukan perlakuan atau treatment terhadap responden/ subjek penelitian.

Efektivitas Sistem Penilaian Dengan CAT Terhadap Kemudahan Dalam Melakukan Evaluasi Kompetensi Peserta Didik

Tabel 6. Analisis Regresi Linier Sistem Penilaian dengan CAT terhadap Kemudahan dalam Melakukan Evaluasi Kompetensi Peserta Didik

\begin{tabular}{llcc}
\hline Model & & F & Sig. \\
\hline 1 & Regression & 9,815 & $0,006^{\mathrm{a}}$ \\
\hline
\end{tabular}

Berdasarkan Tabel 6 dapat diketahui bahwa nilai $\mathrm{F}_{\text {hitung }}$ sebesar 9,851 sedangkan nilai $\mathrm{F}_{\text {tabel }}$ $(0,05)=4,41$. Dapat disimpulkan bahwa terdapat hubungan yang signifikan karena nilai $F_{\text {hitung }}$ $>\mathrm{F}_{\text {tabel }}(0,05)$. Hal itu berarti bahwa terdapat hubungan positif dan signifikan antara sistem penilaian dengan $C A T$ terhadap kemudahan dalam melakukan evaluasi kompetensi peserta didik.

Efektivitas Sistem Penilaian Dengan $C A T$ Terhadap Kenyamanan Dalam Melakukan Evaluasi Kompetensi Peserta Didik

Tabel 7. Analisis Regresi Linier Sistem Penilaian dengan $C A T$ terhadap Kenyamanan dalam Melakukan Evaluasi Kompetensi Peserta Didik

\begin{tabular}{llcc}
\hline Model & & F & Sig. \\
\hline 1 & Regression & 30,600 & $0,000^{\mathrm{a}}$ \\
\hline
\end{tabular}

Berdasarkan Tabel 7 dapat diketahui bahwa nilai $F_{\text {hitung }}$ sebesar 30,600 sedangkan nilai $F_{\text {tabel }}$ $(0,05)=4,41$. Dapat disimpulkan bahwa terdapat hubungan yang signifikan karena nilai $F_{\text {hitung }}$ $>\mathrm{F}_{\text {tabel }(0,05)}$. Hal itu berarti bahwa terdapat hubungan positif dan signifikan antara sistem penilaian dengan $C A T$ terhadap kenyamanan dalam melakukan evaluasi kompetensi peserta didik.

\section{Simpulan dan Saran}

Simpulan

Berdasarkan uraian dari pembahasan, maka dapat disimpulkan bahwa:

1. Sudah dikembangkan aplikasi instrument penilaian dengan system Computer Assist Test (CAT).

2. Sistem penilaian dengan Computer Assist Test (CAT) memiliki korelasi yang kuat terhadap kemudahan dalam melakukan evaluasi kompetensi peserta didik. 
3. Sistem penilaian yang baik maka akan meningkatkan kemudahan dalam melakukan evaluasi kompetensi peserta didik.

4. Sistem penilaian yang baik yang baik maka akan meningkatkan kenyamanan dalam melakukan evaluasi kompetensi peserta didik.

5. Terdapat hubungan positif dan signifikan antara sistem penilaian dengan $C A T$ terhadap kemudahan dalam melakukan evaluasi kompetensi peserta didik.

6. Terdapat hubungan positif dan signifikan antara sistem penilaian dengan $C A T$ terhadap kenyamanan dalam melakukan evaluasi kompetensi peserta didik.

\section{Saran}

Sedangkan saran untuk keberlanjutan kajian penelitian ini adalah:

1. Selain pengembangan instrumen penilaian, hendaknya terdapat penelitian lanjutan yang aspek pengembangannya adalah pada perangkat pembelajarannya. Bagaimana mengembangkan bahan ajar dengan berbantuan computer.

2. Untuk penelitian lanjutan diharapkan dapat mengembangkan suatu strategi pembelajaran yang berbasis komputer untuk semua mata pelajaran yang sudah tervalidasi dan disesuaikan dengan kurikulum yang berlaku.

\section{Daftar Pustaka}

Arikunto, Suharsimi. (1997). Dasar-dasar Evaluasi Pendidikan. Jakarta : Bumi Aksara.

Muhibbin, Syah. (2008). Psikologi Pendidikan dengan Pendekatan Baru. Bandung: PT Remaja Rosdakarya Offset.

Mulyasa, E. Dr., M.Pd. (2003). Manajemen Berbasis Sekolah. Bandung: PT. Remaja Rosdakarya.

Mulyasa, E. Dr., M.Pd. (2007). Standar Kompetensi dan Sertifikasi Guru. Bandung: PT. Remaja Rosda Karya.

Rusman. (2010). Model-model Pembelajaran. Jakarta: PT Raja Grafindo Persada.

Slameto. (2010). Belajar dan Faktor-faktor yang Mempengaruhinya. Jakarta: Bhineka Cipta. 